\title{
IMPACT OF MACROECONOMIC VARIABLES ON THE COMPONENTS OF FINANCIAL STATEMENTS OF LATIN AMERICAN PUBLIC COMPANIES
}

\author{
IMPACTO DAS VARIÁVEIS MACROECONÔMICAS NOS COMPONENTES DOS \\ DEMONSTRATIVOS FINANCEIROS DAS EMPRESAS DE CAPITAL ABERTO DA AMÉRICA \\ LATINA
}

\section{IMPACTO DE LAS VARIABLES MACROECONÓMICAS EN LOS COMPONENTES DE LOS DEMOSTRATIVOS FINANCIEROS DE LAS EMPRESAS DE CAPITAL ABIERTO DE AMÉRICA LATINA}

Recebido em: 07-12-2017

Avaliado em: 19-07-2019

Reformulado em: 06-08-2019

Aceito para publicação em: 14-11-2019

Publicado em: 02-09-2020

Editor Responsável: Tarcísio Pedro da Silva

\author{
Rafael Martins Noriller ${ }^{1}$ \\ César Augusto Tibúrcio Silva²
}

\section{RESUMO}

O presente trabalho tem como objetivos (i) mensurar a relação de causalidade dos indicadores macroeconômicos nos componentes dos demonstrativos financeiros das empresas de capital aberto da América Latina e (ii) determinar a relação dos componentes dos demonstrativos financeiros de empresas de capital aberto da América Latina com suas respectivas variáveis defasadas. Para realização do estudo, foram adotadas estimações por GMM de Arellano e Bond e GMM System, com dados secundários extraídos na Thomson Reuters Eikon e Word Bank. A partir das estimações, que contaram com uma amostra de 150 empresas, ficou evidente a relação de causalidade (i) da taxa de câmbio no Ativo Total, Receita Líquida e Patrimônio Líquido, (ii) do PIB no Patrimônio Líquido e Lucro Líquido e (iii) do Lucro Líquido com sua primeira defasagem. Assim, a presente pesquisa avança da literatura ao demonstrar a influência da macroeconomia, de forma distinta, nos componentes dos demonstrativos financeiros.

Palavras-chave: Indicadores macroeconômicos; Demonstrações financeiras; Empresas latinoamericanas.

\footnotetext{
ABSTRACT

This study (i) measures the causal relationship between macroeconomic indicators and the financial statements of Latin American public companies, (ii) and determines the relationship between components of financial statements of Latin American public companies and their respective lagged variables. To carry out the study, estimates GMM of Arellano and Bond and GMM System were adopted, with secondary data extracted from Thomson Reuters Eikon and Word Bank. From the estimates, which had a sample of 150 companies, identified the causal relationships (i) of the Exchange Rate in Total Assets, Net Revenue and Equity, (ii) of the GDP in Equity and Net Income,

${ }^{1}$ Doutorando em Ciências Contábeis pelo PPGCont da Universidade de Brasília; Professor da FACE da Universidade Federal da Grande Dourados; E-mail: rafael.mnoriller@gmail.com.

${ }^{2}$ Doutor em Controladoria e Contabilidade pela Universidade de São Paulo; Professor do Departamento de Ciências Contábeis da Universidade de Brasília; E-mail: cesaraugustotiburciosilva@gmail.com.
} 
(iii) and Net Income with its first lag. Thus, this research advances the literature by demonstrating the influence of macroeconomics, in a different way, on the components of financial statements.

Keywords: Macroeconomic indicators; financial statements; Latin American companies.

\section{RESUMEN}

El presente trabajo tiene como objetivos (i) medir la relación de causalidad de los indicadores macroeconómicos en los componentes de los estados financieros de las empresas de capital abierto de América Latina y (ii) determinar la relación de los componentes de los estados financieros de empresas de capital abierto América Latina con sus respectivas variables desfasadas. Para la realización del estudio, se adoptaron estimaciones por GMM de Arellano y Bond y GMM System, con datos secundarios extraídos en Thomson Reuters Eikon y Word Bank. A partir de las estimaciones, que contaron con una muestra de 150 empresas, quedó evidente la relación de causalidad (i) del tipo de cambio en el Activo Total, el ingreso neto y el patrimonio neto, (ii) del PIB en el patrimonio neto y el beneficio neto y (iii) del beneficio neto con su primer desfase. Por lo tanto, la presente investigación avanza la literatura al demostrar la influencia de la macroeconomía, de una manera diferente, en los componentes de los estados financieros.

Palabras-clave: Indicadores macroeconómicos; Demostraciones financieras; Empresas latinoamericanas.

\section{INTRODUÇÃO}

Macroeconomics is fundamental for the decision-making process of economic agents, public and private, who demand timely information about the economic activity (Aruoba \& Diebold, 2010). Thus, companies need to be attentive to the macroeconomic environment into which they are inserted for investment or divestment decisions (e.g., Jeon \& Nishihara, 2014), as well as economic and financial positions (e.g., Assaf Neto, 2015).

Several studies highlight the relationship between macroeconomics and business fundamentals such as the negative relation between interest rate and stock return (Yang, Kim, Kim, \& Ryu, 2018), inflation and exchange rate impact on corporate profitability and indebtedness (Fonseca, Oliveira Santos, Pereira, \& Camargos, 2019), and the positive relation between the diversification of products by companies and the GDP (Hautz, Mayer \& Stadler, 2014).

With emphasis on causality, studies report a relation between stock return and macroeconomic variables, be it the GDP (e.g., Silva, Coronel \& Vieira, 2014) inflation indicators (e.g., Barakat, Elgazzar \& Hanafy, 2016), industrial production (e.g. Ray, 2012), exchange rate (e.g., Talla, 2013), or domestic and international macroeconomic factors (e.g., Gay, 2016).

In contrast, studies on causal relationships among macroeconomic variables and the components of financial statements receive little attention by part of the literature. English, Van den Heuvel and Zakrajšek (2018) pointed out that an increase in interest rates results in an increase in revenue and also in the performance of companies in the banking sector. Considering various sectors, Konchitchki and Patatoukas (2014) found a positive relationship between GDP and the aggregate accounting profit of US companies.

Given literature highlights on the relationship of causality of the stock return and macroeconomic variables (e.g., Yang et al, 2018), the importance of macroeconomics for the continuity of organizations (e.g., Doumpos, Andriosopoulos, Galariotis, Makridou, \& Zopounidis, 2017) and the impact of macroeconomics on corporate performance (e.g., Fonseca et al, 2019), it is necessary to conduct further studies on causal relationships between macroeconomic variables and other parameters or business indicators. In other words, to understand the exogenous factors considered relevant for changes in the components of Corporate Financial Statements is fundamental for the user of accounting information. 
Still, another important foundation highlighted by Costa, Prado, Castro Júnior, \& Carvalho (2014) in his research is the use of Vector Autoregressive (VAR) modeling to understand company results. Thus, the modeling allows the variable to be explained also by its lags. Most studies highlight the effect of macroeconomic variables on stock returns. Thus, the present work advances in the literature, considering the influence of exchange rate, interest rate and GDP, concomitantly, on the components of the financial statements of publicly traded companies.

Therefore, this study (i) measures the causal relationship between macroeconomic indicators and the financial statements of Latin American public companies, (ii) and determines the relationship between components of financial statements of Latin American public companies and their respective lagged variables. To that end, this study's structure includes an introduction, theoretical constructs about the causality between macroeconomic variables and companies, econometric procedures used in the research, data analysis and, finally, the final considerations.

The study is justified by highlighting a dissimilar perspective, presenting the effect of macroeconomic variables on the components of the financial statements of companies in Latin America. In time, the work can be further justified by theoretical contributions to complement the works of Konchitchki and Patatoukas (2014), Tarantin Junior and Valle (2015), English et al. (2018), Carabias (2018), Ball, Gallo and Ghysels (2019) and Fonseca et al. (2019).

In practice, the research highlights some contributions, generally, positive relationship of exchange rate and GDP in the components of the financial statements of Latin American companies. Noting, for example, that an increase in GDP will result in an increase in Net Income and that an increase in GDP and the Exchange Rate will result in an increase in Net Revenue. This way, the results can contribute to the users, especially investors.

\section{THEORETICAL CONSTRUCTS}

Macroeconomics seeks to relate aggregate variables. An example is the relationship between the price of oil and the behavior of the United States currency (Fratzscher, Schneider \& Van Robays, 2014). Bresser-Pereira and Galla (2010) point out that companies as well as nations need to look at strategies to maximize economic growth in an increasingly globalized environment.

In this context, accounting, among other objectives, aims to understand the relationship of profitability using other business fundamentals (Resić, Mangafic \& Peric, 2015). Already, Leuz and Wysocki (2016) pointed out in their research the need to consider the economic effects, among other fundamentals, in the disclosure of financial statements aiming to report information for better decision making.

Furthermore, verifying the effects of macroeconomic behavior in companies are necessary for the search for better performance and also for the continuity of these organizations. Li, Richardson and Tuna (2014) have shown relationships between interest rate and corporate profits in the USA and elsewhere. Similares results found by Jackson, Plumlee and Rountree (2018) and Shu, Broadstock and $\mathrm{Xu}$ (2013) in which Macroeconomic interference interferes with profits of companies.

In time, Armenter and Hnatkovska (2017) expose that companies adjust their capital structure considering macroeconomic conditions (e.g., unfavorable (favorable) macroeconomic enviroment in slow (fast) capital structure adjustment). In addition, Bernardo, Albanez and Securato (2018) expose a relationship of macroeconomics (e.g. GDP and inflation rate) and endogenous factors with the leverage in companies in Latin American. Bernanke (2017) emphasized that the fundamentals of monetary policy are indirectly expressed through production and other macroeconomic variables, and directly expressed by the financial companies. Therefore, it is a relationship of paramount importance for companies and macroeconomics.

In this sense, considering the sources of funding presented by the macroeconomics, Tarantin Junior and Valle (2015) found a relationship with debt leverage and maturity in companies listed in Brazilian stock exchange (i.e., B3). In its turn, Bikker and Vervliet (2018) pointed out that a reduction 
in interest rates impacts the profitability of US financial institutions and fundraising by other business sectors.

English et al. (2018) complement highlighting that there is an positive relationship between the interest rate and net income of financial institutions (by the impact on revenue). However, the work of Coibion, Gorodnichenko and Kumar (2018) point out that inflation is not considered important in corporate business decisions. This example shows how the discussion about the effects of macroeconomics can be interesting.

Other macroeconomic variables may interfere with the components of corporate financial statements. Altavilla, Boucinha and Peydro (2018) report that it is not only the interest rate that ultimately interferes with the long-term profitability of financial institutions, but the set of macroeconomic variables (e.g., an improvement in the macroeconomic environment ultimately reduces the effect of a reduction in interest rates). Fonseca et al, (2019) conducted a study with 191 publicly traded Brazilian companies found relationship interest (SELIC) and exchange ratios with capital structure and earnings per share and no significant $10 \%$ inflation ratio with fundamentals of firms. Also, Ball et al. (2019) found a relation between GDP and aggregate earnings of US companies.

Considering exchange rate, a valuation of the local currency may exclude companies from the international market (e.g., Bresser-Pereira \& Gala, 2010), affecting their financial statements. From this point of view, Bhargava (2014) found a causal relationship between interest rates and the investment policy of companies, where a decrease in interest rates would result in an increase in investments.

In addition, Jiménes et al. (2012), in Spain, stated that environments with more rigid monetary conditions may result in increases in financing costs and in decreases in investment levels and Hautz, et al. (2014), a survey of European companies, points out that there is a positive relationship between GDP and product diversification by companies. Doumpos et al., (2017) highlight the importance of national policy on the continuity of organizations. Jeon and Nishihara (2014) reinforce that companies' investment activity is affected by economic situation.

Moll (2014) emphasizes that macroeconomic variables end up interfering differently in production. In other words, in developed (developing) countries resource allocation is done more (less) efficiently. Already, Begenau, Farboodi and Veldkamp (2018) note that large companies have better performance justified by the greater capacity of processing endogenous and macroeconomic information, the research counted on companies listed in the S\&P 500. In addition, Bai, Lu and Tian (2018) did a job with Chinese firms and found that small companies have less leverage than large companies because they face higher interest rates (the work criticizes the aggregation of previous research variables).

Kalemli-Ozcan, Kamil and Villegas-Sanchez (2016) conducted a study of companies in Latin American countries highlighting that in unfavorable economic environments exporting companies reduce investment. Atkeson, Eisfeldt and Weill (2017) conducted research with US companies and pointed out that in the economic downturns (e.g., 1937 and 2008) companies end up at risk in their continuity, e.g., insolvency.

In short, such studies and books describe the causal relationships between macroeconomic variables and corporate financial statements. However, empirical evidence may differ, considering the markets (e.g., comparison of sample from developed countries and sample from developing countries) on which previous studies were conducted.

\section{METHODOLOGICAL PROCEDURES}

This is a quantitative study. According to Collis and Hussey (2013), quantitative studies focus on measuring phenomena from numerical data collection to the application of statistical tests. This strategy encompasses propositions that lead to the collection and data analysis from various sources of evidence. 
This study was conducted on 30 public companies with the highest total assets on 12/31/2016 from five Latin American countries: Argentina, Brazil, Chile, Peru and Mexico, totaling 150 companies. We excluded from the sample companies with unavailability of information for the period encompassed by the research.

Five countries were selected intentionally because of representing more than $73 \%$ of the Gross Domestic Product of the calendar year 2016 in Latin America, according to the World Bank (2017). Regarding companies, the sampling was also intentionally due to the accessibility to financial statements, the importance for national economy, and because of their high liquidity (e.g., Bernardelli \& Bernardelli, 2016; Nardy, Famá, Guevara, \& Mussa, 2015).

The Thomson Reuters Eikon database was used in this research because it presented financial and macroeconomic information of companies in the Latin American stock market and also because it presented official information from the federal governments of the research countries complemented by World Bank data (2017).

Regarding financial statements and macroeconomic variables, data collection was performed annually from 2010 to 2016 for Brazil and from 2012 to 2016 for Argentina, Chile, Mexico and Peru. In this context, the IASB (2017) highlights the total compulsory convergence of Brazilian companies to the International Financial Reporting Standards (IFRS) from 2010 and from 2012 for companies from Argentina, Chile, Mexico and Peru. Such convergence may jeopardize the data analysis from previous periods due to differences in the recognition and measurement of elements in the financial statements, e.g., the impairment test.

Table 1 - Justification of variables

\begin{tabular}{|c|c|c|c|}
\hline $\begin{array}{c}\text { Independent } \\
\text { Variable }\end{array}$ & $\begin{array}{c}\text { Dependent } \\
\text { Variable }\end{array}$ & $\begin{array}{c}\text { Expected relation } \\
\text { between the } \\
\text { dependent and the } \\
\text { independent variable }\end{array}$ & Justification \\
\hline $\begin{array}{l}\text { Interest Rate } \\
\text { (IR) }\end{array}$ & $\begin{array}{l}\text { Total Assets (TA) } \\
\text { Equity (EQ) } \\
\text { Net Revenue(NR) } \\
\text { Net Income (NI) }\end{array}$ & $\begin{array}{l}\text { Negative } \\
\text { Negative } \\
\text { Negative } \\
\text { Negative }\end{array}$ & $\begin{array}{l}\text { In monetary policy, the interest rate is fundamental to } \\
\text { macroeconomics (Kiley \& Roberts, 2017). Ehrhanrdt } \\
\text { and Brigham (2014) argued that the interest rate } \\
\text { exerts a significant effect on the company's } \\
\text { profitability. The increase in interest rate reduces the } \\
\text { net income, net revenue, assets and equity. }\end{array}$ \\
\hline $\begin{array}{l}\text { Exchange } \\
\text { Rate } \\
\text { (ER) }\end{array}$ & $\begin{array}{l}\text { TA } \\
\text { EQ } \\
\text { NR } \\
\text { NI }\end{array}$ & $\begin{array}{l}\text { Negative } \\
\text { Negative } \\
\text { Negative } \\
\text { Negative }\end{array}$ & $\begin{array}{l}\text { Blanchard (2011) stated that exchange rate is } \\
\text { important for a country's macroeconomic policy. In } \\
\text { turn, Assaf Neto (2015) asserted that the exchange } \\
\text { rate has important consequences for the economy. An } \\
\text { increase in the exchange rate may reduce the } \\
\text { company's net revenues, resulting in a decrease in net } \\
\text { income, equity and assets of the organizations (e.g., } \\
\text { Bresser-Pereira \& Galla, 2010). }\end{array}$ \\
\hline $\begin{array}{l}\text { Gross } \\
\text { Domestic } \\
\text { Product } \\
\text { (GDP) }\end{array}$ & $\begin{array}{l}\text { TA } \\
\text { EQ } \\
\text { NR } \\
\text { NI }\end{array}$ & $\begin{array}{l}\text { Positive } \\
\text { Positive } \\
\text { Positive } \\
\text { Positive }\end{array}$ & $\begin{array}{l}\text { The GDP measures the national economic } \\
\text { performance. Increases in GDP are related to a high } \\
\text { income and production of goods and services } \\
\text { (Mankin, 2016). An increased production of goods } \\
\text { and services results in a higher economic activity of } \\
\text { companies (Samuelson, 2017) due to increasing } \\
\text { revenues. This is a situation in which net income } \\
\text { (Konchitchki \& Patatoukas, 2014), assets and equity } \\
\text { are expected to increase. }\end{array}$ \\
\hline
\end{tabular}

Source: Research data.

Thus, the study had panel data, justifying (i) the difficulty of measuring and interpreting 5 countries separately (eg, aggregating the profit of Argentine companies) through time series from five observations after total convergence to IFRS (e.g., Argentina) and (ii) advantages highlighted by 
Baltagi (2013) when compared to Time Series and Cross Section, e.g., lower collinearity between variables and greater variability

Concerning to macroeconomic indicators, we selected the main indicators reported in the literature that related to the components of corporate financial statements selected for this research. The causality relation was obtained by macroeconomic indicators, assuming a condition of independent variables in counterpoint to the variables extracted from corporate financial statements.

Regarding the components of financial statements, this research took into account (1) Net Revenue (NR), (2) Net Income (NI), (3) Total Assets (TA) and (4) Equity (EQ); in a macroeconomic context, (1) Real Interest Rate, (2) Exchange Rate and (3) GDP. Table 1 presents justifications and the expected results of causal relationships.

In the research, robustness tests of all business and macroeconomic variables were performed. Using macroeconomic variables and components of financial statements of companies, it was possible to interpret causality relations. Table 1 presents justifications and expected results of the causal relationship.

For data collection, e.g., in Brazil, the real interest rate adopted in the research is the federal government's Special System of Liquidation and Custody (SELIC) rate after deducting the inflation of the period obtained by the IPCA. For all sampled countries, an exchange rate obtained by converting the local currency to a non-closed US Commercial Dollar quotation for the calendar year was considered. Finally, the GDP of the dollar countries, as it reflects economic transactions carried out by companies in international market.

As for the analysis, the Vector Autoregressive with Contemporary Exogenous Variables (VARX) was used according to VARX equations (1):

$$
\begin{gathered}
T A y_{i t}=T A_{0}+T A y_{i t-1}+I R x_{i t}+E R x_{i t}+G D P x_{i t} \\
E Q y_{i t}=E Q_{0}+E Q_{1} y_{i t-1}+I R x_{i t}+E R x_{i t}+G D P x_{i t} \\
N R y_{i t}=N R_{0}+N R_{1} y_{i t-1}+I R x_{i t}+E R x_{i t}+G D P x_{i t} \\
N I y_{i t}=N I_{0}+N I_{1} y_{i t-1}+I R x_{i t}+E R x_{i t}+G D P x_{i t}
\end{gathered}
$$

The VAR also offers the possibility of including contemporary exogenous variables in the model. With this, VARX works with the Vector Autoregressive of the endogenous variable and also of exogenous variables without any lags (Brooks, 2014). Many studies used the VAR for its ability to detect temporal effects, e.g. discretionary fiscal policy and macroeconomics (Hebous, 2011). In turn, the Generalized Method of Moments (GMM) estimator is a generalization of the moments (MM) method, which became more popular in recent years (Gujarati \& Porter, 2011). It is popular due to studies conducted using the GMM estimator for analyses, e.g., the list of traditional performance indicators of Brazilian companies (e.g., Kruger \& Petri, 2014).

Thus, the estimation was performed using the Generalized Method of Moments (GMM) of Arellano and Bond (AB), and the GMM System as corrected by Windmeijer (2005) for robustness estimates. Arellano and Bond (1991) focused on a model that has individual effects and lagged endogenous variables, working with the first difference. The GMM System, however, proposed by Arellano and Bover (1995) and Blundell and Bond (1998), combine equations in difference with the set of variables in levels.

Other methodologies could be used to verify causality, emphasizing the Granger causality test, which is adopted in several studies. It takes into account stock return together with macroeconomic variables (e.g., Ray, 2012; Barakat et al., 2016).

Granger's causality test was not adopted in this research because this technique works with only two variables and does not consider contemporary exogenous variables. In turn, the mixed 
method may generate validated and substantiated results, as Creswell (2013) states, and will not be used due to the difficulty of obtaining a qualitative data sample.

\section{ANALYSIS AND DISCUSSION OF RESULTS}

To verify the impact of macroeconomic variables on the components of financial statements, all variables of the research were collected from Thomson Reuters Eikon, supplemented by the World Bank (2017), and estimated using Stata 12 software.

Descriptive statistics, shown in Table 2, allows stating that: (i) the average assets of the companies are US\$28.664 billion; (ii) the annual net income represents, on average, $2.28 \%$ of the total TA assets the end of the period and $8.77 \%$ of the annual revenue of companies; and (iii) all business and macroeconomic variables presented a high coefficient of variation (greater than 20\%). In addition, the real interest rate averaged $-0.39 \%$ per year, and the exchange rate averaged US\$ 0.2079 .

Table 2 - Descriptive Statistics (* in millions of dollars)

\begin{tabular}{lcccccc}
\hline Variáveis & Observações & Média & Máximo & Mínimo & $\begin{array}{c}\text { Desvio } \\
\text { Padrão }\end{array}$ & $\begin{array}{c}\text { Coeficiente de } \\
\text { Variação }\end{array}$ \\
\hline TA* & 810 & $28,664.77$ & $497,756.7$ & 168.02 & $72,986.1$ & $254 \%$ \\
D(Ln(TA)) & 660 & 0.0134 & 2.24 & -2.11 & 0.2306 & $1,720.8 \%$ \\
EQ* & 810 & $6,055.50$ & $184,876.3$ & -344.0 & $15,183.8$ & $250 \%$ \\
D(EQ) & 660 & -364.68 & $16,228.29$ & $-51,901.98$ & $3,176.16$ & $870.9 \%$ \\
NI*(a.a.) & 810 & 654.68 & $21,624.4$ & $-11,450.6$ & $1,997.39$ & $305 \%$ \\
Ln(NI) & 717 & 5.56 & 9.98 & -3.13 & 1.59 & $28.7 \%$ \\
NR*(a.a.) & 810 & $7,462.96$ & $137,425.6$ & 2.0655 & $14,474.1$ & $193 \%$ \\
\% (NR) & 659 & 0.0400 & 8.22 & -0.9265 & 0.5333 & $1,333.2$ \\
ER (U\$) & 810 & 0.2079 & 0.6026 & 0.0014 & 0.1807 & $86.9 \%$ \\
D(ER) & 810 & -0.0197 & 0.0548 & -0.1237 & 0.0346 & $175.2 \%$ \\
IR (a.a.) & 810 & -0.0039 & 0.04809 & -0.1122 & 0.0419 & $1,064.7 \%$ \\
D(IR) & 810 & -0.0068 & 0.0297 & -0.0947 & 0.0267 & $390.7 \%$ \\
GDP & 810 & $988,049.10$ & $2,614,573.0$ & $189,024.0$ & 834,540 & $84.4 \%$ \\
$\% \Delta$ (GDP) & 810 & 0.0073 & 0.3233 & -0.2657 & 0.1034 & $1,416.4 \%$ \\
\hline Source: Res & & & & &
\end{tabular}

Source: Research data (2017).

Note: $\mathrm{D}(\operatorname{Ln}(\mathrm{TA}))$ represents the first difference of the natural logarithm of total assets, $D(E Q)$ represents the first difference of Equity, $\mathrm{Ln}(\mathrm{NI})$ represents the natural logarithm of net income, $\% \Delta(\mathrm{NR})$ represents the percentage variation of net revenue, $\mathrm{D}(\mathrm{ER})$ represents the first difference of exchange rate, $\mathrm{D}(\mathrm{IR})$ represents the first difference of real interest rate and $\% \Delta(\mathrm{GDP})$ represents the percentage variation in GDP, respectively.

Table 3 shows the correlations among the macroeconomic variables adopted in this research. It is not necessary to make adjustments to the variables. The Variance Inflation Factors test (VIF) indicates an absence of multicollinearity of macroeconomic variables, since they presented values lower than 5 (e.g., Fávero, Belfiore, Silva, \& Chan, 2009). With respect to the normality of residuals, the Central Limit Theorem was used, which assumes the normality of residues in samples with more than 100 observations (Gujarati \& Porter, 2011).

Table 3 - Pearson Correlation Matrix (VIF)

\begin{tabular}{cccc}
\hline VARIABLES & D(ER) & D(IR) & \% $($ GDP $)$ \\
\hline $\mathrm{D}(\mathrm{ER})$ & 1 & $(1.09)$ & $(1.67)$ \\
$\mathrm{D}(\mathrm{IR})$ & -0.0810 & 1 & $(1.18)$ \\
$\% \Delta(\mathrm{GDP})$ & 0.4009 & 0.1513 & 1 \\
\hline
\end{tabular}

Source: Research data (2017).

The variables $\mathrm{D}(\mathrm{ER}), \mathrm{D}(\mathrm{IR}), \% \Delta(\mathrm{GDP}), \mathrm{D}(\mathrm{Ln}(\mathrm{TA})), \% \Delta(\mathrm{EQ}), \mathrm{Ln}(\mathrm{NI})$ and $\% \Delta(\mathrm{NR})$ were stationary in option with no intercept and no tendency by the Increased Dickey-Fuller test - Fisher - 
and also in the individual intercept option by Levin, Lin and Chu, and Im, Pesaran and Shin tests with a significance level of 5\% (Baltagi, 2013). Furthermore, estimates by GMM AB and GMM System are consistent with endogeneity.

For the purpose of determining the number of lags of the dependent variable adopted in the research regressions, estimates were made by AB2 (Arellano-Bond two-step), emphasizing the low number of lags for the model. Attention was given to robustness tests proposed by Arellano and Bond (1991) for overidentification and autocorrelation (first order and second order): respectively, the Sargan and Abond tests.

Finally, in the regressions of Tables 4, 5, 6 and 7, estimates were made by GMM AB two-step and GMM system two-step corrected by Windmeijer (2005) for robust estimates to the detriment of heteroscedasticity.

\subsection{Total Assets and Macroeconomic Variables}

Estimates in Table 4 shows Total assets (TA) as an independent variable by means of its first difference of natural logarithm, D ( $\ln (\mathrm{TA}))$. Wald's F test initially confirmed estimates validity.

Afterwards, the GMM AB Robust (1) and GMM-System Robust (2) estimates did not reject the hypothesis that overidentification constraints are valid and rejected (not rejected) the hypothesis of no autocorrelation of first (second) order (e.g., Baltagi, 2013), thus validating the estimated parameters.

Table 4 - Estimates of the Model with dependent variable: D $(\ln (\mathrm{TA}))$

\begin{tabular}{lcc}
\hline Variables/Tests & $\begin{array}{c}\text { Estimation 1 } \\
\text { GMM-AB Robust }\end{array}$ & $\begin{array}{c}\text { Estimation 2 } \\
\text { GMM-System Robust }\end{array}$ \\
\hline $\mathrm{D}\left(\ln \left(\mathrm{TA} \mathrm{t}_{\mathrm{t}-1}\right)\right)$ & 0.0798 & -0.0362 \\
$\% \Delta(\mathrm{GDP})$ & -0.0131 & 0.0231 \\
$\mathrm{D}(\mathrm{ER})$ & $2.36^{* * *}$ & $2.33^{* * *}$ \\
$\mathrm{D}(\mathrm{IR})$ & 0.6208 & 0.3885 \\
Intercept & $0.0659^{* * *}$ & $0.0633^{* * *}$ \\
\hline P-valor - Wald test & 0.0000 & 0.0000 \\
$\mathrm{AB}-\mathrm{H}_{0}$ : There is no autocorrelation in the first order. & 0.0049 & 0.0096 \\
$\mathrm{AB}-\mathrm{H}_{0}$ : There is no autocorrelation in the second order. & 0.2015 & 0.1907 \\
Estat Sargan & 0.4760 & 0.4411 \\
\hline Source: Resar
\end{tabular}

Source: Research data (2017).

Note: $*, * *, * *$ indicative of a significance of 10,5 and $1 \%$, respectively.

The estimates 1 and 2 indicated a positive and significant relation at $1 \%$ between the variable $\mathrm{D}(\mathrm{ER})$ and $\mathrm{D}(\ln (\mathrm{TA}))$. Thus, the macroeconomic variable exchange rate had a relation with the total assets of the companies, but with a positive sign in disagreement with the work of Bresser-Pereira and Gallo (2010) and Yang et al. (2018), possibly considering different samples and period in the surveys, i.e., different institutional environments.

Other macroeconomic variables and the lag of the dependent variable did not have significant relations at 10\%, refuting the works by Joshi and Giri (2015), Konchitchki and Patatoukas (2014) and Jeon and Nishihara (2014). Despite the absence of a significance of $10 \%$, the $\% \Delta$ (GDP) presented a positive relation in the two estimates according to the work of Cohen and Scatigna (2016). Finally, the intercept presented a positive and significant signal at $1 \%$ in both estimates.

In particular, only the exchange rate is related to the total assets of Latin American companies. A possible justification would be that the quotation of the main products produced in Latin America, commodities, are quoted in US dollars, e.g., a reduction in US dollar prices would result in a reduction in total assets. Another possible justification would be the macroeconomic policy adopted in Latin American countries. 


\subsection{Equity and Macroeconomic Variables}

In turn, the variable representing equity (EQ) could be verified based on the estimates shown in Table 5 by means of percentage variation, $\% \Delta(\mathrm{NE})$. Furthermore, the Wald $\mathrm{F}$ test confirms the validity of estimates.

Thus, the GMM AB Robust (1) and GMM-System Robust (2) estimates did not reject the hypothesis that overidentification constraints are valid and rejected (not rejected) the hypothesis of no autocorrelation of first (second) order, thus validating the estimated parameters.

Table 5 - Estimates of the Model with dependent variable: $\% \Delta(\mathrm{EQ})$

\begin{tabular}{lcc}
\hline Variables/Tests & $\begin{array}{c}\text { Estimation 1 } \\
\text { GM-AB Robust }\end{array}$ & $\begin{array}{c}\text { Estimation 2 } \\
\text { GMM-System Robust }\end{array}$ \\
\hline$\% \Delta\left(\mathrm{EQ}_{\mathrm{t}-1}\right)$ & 0.0202 & -0.0008 \\
$\% \Delta(\mathrm{GDP})$ & $0.8462^{* *}$ & $0.7540^{* * *}$ \\
$\mathrm{D}(\mathrm{ER})$ & $1.41^{* *}$ & $1.64 * *$ \\
$\mathrm{D}(\mathrm{IR})$ & 0.3423 & 0.5104 \\
Intercept & $0.0639^{* * *}$ & $0.0631^{* * *}$ \\
\hline P-valor - Wald test & 0.0000 & 0.0000 \\
AB - H $\mathrm{H}_{0}$ There is no autocorrelation in the first order. & 0.0070 & 0.0077 \\
AB - H $\mathrm{H}_{0}$ There is no autocorrelation in the second order. & 0.8268 & 0.6544 \\
Estat Sargan & 0.1440 & 0.1190 \\
\hline Source: Resar
\end{tabular}

Source: Research data (2017).

Note: $*, * *, * * *$ indicative of a significance of 10,5 and $1 \%$, respectively.

Therefore, estimates indicate a positive relation between $\% \Delta(\mathrm{GDP})$ and $\% \Delta(\mathrm{EQ})$, being significant at $1 \%$ in the estimation 2 and significant at $5 \%$ in the estimation 1 , respectively. It is a positive relationship in line with the work of Mai, Meng and Ye (2017) conducted in certain regions of China, Armenter and Hnatkovska (2017) in US non-financial firms and Tarantin Junior and Valle (2015) in Brazil.

The variable $\mathrm{D}(\mathrm{IR})$ did not present a significant relation at $10 \%$, contradicting the work Konchitchki (2011). A possible justification for this result is the adoption of real interest rate in this research to the detriment of inflation or nominal interest rates. In turn, D(ER) presented a positive and significant relation to 5\% in disagreement with the work of Fonseca et al. (2019), however, in line with the result obtained with the total assets.

In general, the result obtained here is in line with the work of Altavilla et al. (2018), i.e., noting that the interest rate effect can be offset by other macroeconomic variables. Finally, the intercept presented a positive and significant relationship at $1 \%$ and the lag of the dependent variable did not present a significant relation at $10 \%$.

\subsection{Net Revenue and Macroeconomic Variables}

In reference to the variable net revenue (NR), the estimates are shown in Table 6. Initially, the Wald test $\mathrm{F}$ attested estimates validity. It was necessary to adopt the $\Delta \%(\mathrm{NR})$ of the observations.

Later, only the GMM AB Robust (1) estimate was valid, not rejecting the hypothesis that overidentification constraints are valid and rejecting (not rejecting) the hypothesis of no autocorrelation of first (second) order, thus validating the estimate parameters. The estimation by GMM-System Robust (2) is not valid, which is justified by the non-rejection of the hypothesis of absence of first order autocorrelation.

Therefore, the estimation 1 indicates a negative and non-significant relation at $10 \%$ of D(IR) with $\Delta \%(\mathrm{NR})$. Although not significant at $10 \%$, the result corroborates the expected signal of the relation in accordance with Kiley and Roberts (2017), who collected a sample of 54 countries. 
The variable $\% \Delta(\mathrm{GDP})$ presented a negative relation and non-significance of $10 \%$. This is contrary to the work of Hautz et al. (2014), which highlighted the impact of GDP positively on corporate net income, possibly for portraying different countries in their sample (Gulser et al., 2016).

Table 6 - Estimates of the Model with dependent variable: $\Delta \%(\mathrm{NR})$

\begin{tabular}{|c|c|c|}
\hline Variables/Tests & $\begin{array}{c}\text { Estimation 1 } \\
\text { GMM-AB Robust } \\
\end{array}$ & $\begin{array}{c}\text { Estimation 2 } \\
\text { GMM-System Robust }\end{array}$ \\
\hline$\Delta \%\left(\mathrm{NR}_{\mathrm{t}-1}\right)$ & -0.0243 & -0.0681 \\
\hline$\% \Delta(\mathrm{GDP})$ & -0.3524 & -0.2868 \\
\hline $\mathrm{D}(\mathrm{ER})$ & $3.32 * * *$ & $3.17 * * *$ \\
\hline $\mathrm{D}(\mathrm{IR})$ & -0.121 & -0.1876 \\
\hline Intercept & $0.0609 * *$ & $0.06359 * * *$ \\
\hline P-valor - Wald test & 0.0000 & 0.0000 \\
\hline $\mathrm{AB}-\mathrm{H}_{0}$ : There is no autocorrelation in the first order. & 0.0369 & 0.0549 \\
\hline $\mathrm{AB}-\mathrm{H}_{0}$ : There is no autocorrelation in the second order. & 0.6162 & 0.6288 \\
\hline Estat Sargan & 0.2562 & 0.2759 \\
\hline
\end{tabular}

Source: Research data (2017).

Note: $* * *, * * *$ indicative of a significance of 10,5 and $1 \%$, respectively.

The $\mathrm{D}(\mathrm{ER})$ indicated positive and significant relationship at $1 \%$ with $\Delta \%(\mathrm{NR})$, corroborating English et al. (2018). Results obtained by NR in line with TA, i.e., relation to exchange rate only. Finally, in the estimation, the first lag of the dependent variable showed no significant relationship at $10 \%$, and the constant showed positive and significant relationship at $5 \%$.

\subsection{Net Income and Macroeconomic Variables}

Finally, we present the analysis of the interest variable net income (NI). For the validation of estimates, its natural logarithm was used (Ln(NI)), excluding 93 observations, i.e., accounting losses. The validity of GMM AB Robust (1) and GMM-System Robust (2) estimates for net result is shown in Table 7 according to Wald $\mathrm{F}$, autocorrelation and overidentification tests.

Table 7 - Estimates of the Model with dependent variable: $\operatorname{Ln}(\mathrm{NI})$

\begin{tabular}{lcc}
\hline Variables/Tests & $\begin{array}{c}\text { Estimation 1 } \\
\text { GM-AB Robust }\end{array}$ & $\begin{array}{c}\text { Estimation 2 } \\
\text { GMM-System Robust }\end{array}$ \\
\hline $\mathrm{Ln}\left(\mathrm{NI}_{\mathrm{t}-1}\right)$ & $0.7633^{* *}$ & $0.4350^{*}$ \\
$\% \Delta(\mathrm{GDP})$ & $0.7367 * *$ & $1.06^{* * *}$ \\
$\mathrm{D}(\mathrm{ER})$ & 0.7633 & -0.3327 \\
$\mathrm{D}(\mathrm{IR})$ & 0.1672 & -0.5453 \\
Intercept & 1.29 & $3.04 * *$ \\
\hline P-valor - Wald test & 0.0000 & 0.0002 \\
$\mathrm{AB}-\mathrm{H}_{0}:$ There is no autocorrelation in the first order. & 0.0145 & 0.0210 \\
$\mathrm{AB}-\mathrm{H}_{0}:$ There is no autocorrelation in the second order. & 0.9175 & 0.6932 \\
Estat Sargan & 0.8074 & 0.3581 \\
\hline
\end{tabular}

Source: Research data (2017).

Note: $*, * *, * * *$ indicative of a significance of 10,5 and $1 \%$, respectively.

The positive relation between net income and the variable $\% \Delta$ (GDP), significant at $5 \%$ in the estimation 1 and significant at $1 \%$ in the estimation 2, is evident, corroborating with the expected result (Konchitchki \& Patatoukas, 2014). In other words, only the economic growth was related to the net income of Latin American companies.

$\mathrm{D}(\mathrm{ER})$ and $\mathrm{D}(\mathrm{IR})$ showed no significant relation, contrary to Li et al. (2014) and Borio, Gambacorta and Hofmann (2017). The unexpected result may be because of the research containing companies from Latin America, different from samples of the aforementioned studies.

The first lag of the dependent variable presented a positive and significant relation at 5 and $10 \%$, respectively, for the estimates 1 and 2 . Finally, the intercept presented a positive relation in both 
estimations, however significant at 5\% only in the estimation 2. In short, only GDP relative to the net income of Latin American companies in accordance with the work of Jackson et al. (2018), Carabias (2018) and Ball et al. (2019).

In line with TA, EQ and NR, NI has no interest rate relationship possibly because (i) it considers the real interest rate to the detriment of the base interest rate (e.g. Fonseca et al, 2019) or (ii) the effect of other macroeconomic variables ends up reducing the interest rate effect, i.e., interest rate changes may be offset by the macroeconomic environment (e.g. Altavilla et al., 2018).

Confirming the works highlighted earlier, the results obtained with this analysis indicate that there is a relationship between macroeconomics and the components of the financial statements. Advancing with respect to the relationship of macroeconomic variables differently in the components of the financial statements, for example, (i) exchange rate to TA ratio and (ii) GDP to NI.

\section{FINAL CONSIDERATIONS}

This study (i) measured the causal relationships between macroeconomic indicators and the financial statements of Latin American public companies in a contemporary way and (ii) determined the relationships between components of financial statements of Latin American public companies and their respective lagged variables using VARX with GMM estimation as proposed by Arellano and Bond (1991) and GMM System as proposed by Arellano and Bover (1995) and Blundell and Bond (1998).

We performed (i) data collection on Thomson Reuters Eikon and the World Bank (2017); (ii) sample selection with full data availability for the entire analysis period; (iii) application of the estimates GMM AB and GMM System; (iv) analysis and interpretation of the econometric results found in this research.

As a result, the causality positive relation between exchange rate and the components of financial statements, total assets (significant at 1\%), net revenue (significant at $1 \%$ ) and equity (significant at $5 \%$ ) was characterized. The $\% \Delta \mathrm{GDP}$ showed a positive and significant causality relation at $5 \%$ (yet significant at $1 \%$ only in the estimation 2 ) with equity and net income. In turn, the real interest rate did not present a significant causality relation at $10 \%$ with the dependent variables of this research. Thus, the causality of GDP and exchange rate in the components of financial statements is evidenced, corroborating with previous research (e.g. Konchitchki \& Patatoukas, 2014; Altavilla et al., 2018). Thus, this research advances the literature by demonstrating the influence of macroeconomics, in a different way, on the components of financial statements (e.g. GDP influencing Net Income and GDP not influencing (significant at 10\%) Total Assets.

Considering the first lag of the dependent variable, it is possible to observe only a positive and significant causal relationship in $10 \%$ (yet significant at $5 \%$ only in the estimate 1) for net income. Finally, total assets, equity and net revenue did not present a significant relation at $10 \%$ with their respective lags.

The research was conducted with only 150 Latin American public companies, making it impossible to generalize to all companies in Latin America. As a suggestion for new studies, we may mention that a sample with a greater diversity of countries, e.g., the G7 or G20, would allow the confirmation of the findings. Another possibility is to consider macroeconomic variables with lags to the detriment of a contemporary approach, the VARX.

\section{REFERÊNCIAS}

Altavilla, C., Boucinha, M., \& Peydró, J. L. (2018). Monetary policy and bank profitability in a low interest rate environment. Economic Policy, 33(96), 531-586.

Arellano, M., Bond, Stephen. Some tests of specification for panel data: Monte Carlo evidence and an application to employment equations. The review of economic studies, 1991, 58.2: 277-297.

Arellano, M., \& Bover, O. (1995). Another look at the instrumental variable estimation of error-components models. Journal of econometrics, 68(1), 29-51. 
Armenter, R., \& Hnatkovska, V. (2017). Taxes and capital structure: Understanding firms' savings. Journal of Monetary Economics, 87, 13-33.

Aruoba, S. B., \& Diebold, F. X. (2010). Real-time macroeconomic monitoring: Real activity, inflation, and interactions. American Economic Review, 100(2), 20-24.

Assaf Neto, A. (2015). Mercado Financeiro, 13a ediçâo. Sâo Paulo, Editora Atlas SA.

Atkeson, A. G., Eisfeldt, A. L., \& Weill, P. O. (2017). Measuring the financial soundness of US firms, 19262012. Research in Economics, 71(3), 613-635.

Bai, Y., Lu, D., \& Tian, X. (2018). Do Financial Frictions Explain Chinese Firms' Saving and Misallocation? (No. w24436). National Bureau of Economic Research.

Ball, R. T., Gallo, L., \& Ghysels, E. (2019). Tilting the evidence: the role of firm-level earnings attributes in the relation between aggregated earnings and gross domestic product. Review of Accounting Studies, 24(2), 570-592.

Baltagi, B. (2013). Econometric analysis of panel data. John Wiley \& Sons.

Barakat, M. R., Elgazzar, S. H., \& Hanafy, K. M. (2016). Impact of macroeconomic variables on stock markets: Evidence from emerging markets. International journal of economics and finance, 8(1), 195207.

Begenau, J., Farboodi, M., \& Veldkamp, L. (2018). Big data in finance and the growth of large firms. Journal of Monetary Economics, 97, 71-87.

Bernanke, B S. (2017). Monetary policy in a new era. Prepared for conference on Rethinking Macroeconomic Policy, Peterson Institute, Washington DC, October 12-13.

Bernardelli, L. V., \& Bernardelli, A. G. (2016). Análise sobre a Relação do Mercado Acionário com as Variáveis Macroeconômicas no Período de 2004 a 2014. Revista Evidenciação Contábil \& Finanças, 4(1), 4-17.

Bernardo, C. J., Albanez, T., \& Securato, J. R. (2018). Fatores Macroeconômicos e Institucionais, Composição do Endividamento e Estrutura de Capital de Empresas Latino-Americanas. Brazilian Business Review, 15(2), 152-174.

Bhargava, A. (2014). Firms' fundamentals, macroeconomic variables and quarterly stock prices in the US. Journal of econometrics, 183(2), 241-250.

Bikker, J. A., \& Vervliet, T. M. (2018). Bank profitability and risk-taking under low interest rates. International Journal of Finance \& Economics, 23(1), 3-18.

Blanchard, O. (2011). Macroeconomia. $5^{\text {a }}$ edição. 2011.

Blundell, R., \& Bond, S. (2000). GMM estimation with persistent panel data: an application to production functions. Econometric reviews, 19(3), 321-340.

Borio, C., Gambacorta, L., \& Hofmann, B. (2017). The influence of monetary policy on bank profitability. International Finance, 20(1), 48-63.

Bresser-Pereira, L. C., \& Gala, P. (2010). Macroeconomia estruturalista do desenvolvimento. Brazilian Journal of Political Economy, 30(4), 663-686.

Chris, B. (2014). Introductory econometrics for finance, 3rd Editio.

Carabias, J. M. (2018). The real-time information content of macroeconomic news: implications for firmlevel earnings expectations. Review of Accounting Studies, 23(1), 136-166.

Cohen, B. H., \& Scatigna, M. (2016). Banks and capital requirements: channels of adjustment. Journal of Banking \& Finance, 69, S56-S69.

Coibion, O., Gorodnichenko, Y., \& Kumar, S. (2018). How do firms form their expectations? new survey evidence. American Economic Review, 108(9), 2671-2713.

Collis, J., \& Hussey, R. (2013). Business research: A practical guide for undergraduate and postgraduate students. Macmillan International Higher Education.

Costa, D. F., do Prado, J. W., de Castro Júnior, L. G., \& de Melo Carvalho, F. (2014). Estimando o Orçamento de Resultado em uma Empresa Varejista: uma abordagem por meio de vetor autorregressivo-VAR. Exacta, 12(3), 279-291.

Creswell, J. W., \& Creswell, J. D. (2017). Research design: Qualitative, quantitative, and mixed methods approaches. Sage publications.

Doumpos, M., Andriosopoulos, K., Galariotis, E., Makridou, G., \& Zopounidis, C. (2017). Corporate failure prediction in the European energy sector: A multicriteria approach and the effect of country characteristics. European Journal of Operational Research, 262(1), 347-360. 
Ehrhardt, M. C., \& Brigham, E. F. (2012). Administração financeira: teoria e prática. São Paulo: Cengage Learning.

English, W. B., Van den Heuvel, S. J., \& Zakrajšek, E. (2018). Interest rate risk and bank equity valuations. Journal of Monetary Economics, 98, 80-97.

Fávero, L. P. L., Belfiore, P. P., Silva, F. L. D., \& Chan, B. L. (2009). Análise de dados: modelagem multivariada para tomada de decisões.

Fonseca, S. E., de Oliveira Santos, A., Pereira, M. V. L., \& de Camargos, M. A. (2019). Análise do Impacto de Variáveis Macroeconômicas no Desempenho Financeiro e Endividamento de Empresas Listadas na B3. Revista Universo Contábil, 14(4), 93-114.

Fratzscher, M., Schneider, D., Van Robays, I. (2014) Oil prices, exchange rates and asset prices. ECB Working Paper, n. 1689.

Gay, R. D. (2016). Effect of macroeconomic variables on stock market returns for four emerging economies: Brazil, Russia, India, and China. International Business \& Economics Research Journal (Iber), 15(3), 119-126.

Gujarati, D. N, Porter, D. C. (2011). Basic Econometrics. McGraw-Hill Higher Education.

Gülser, C., Ekberli, I., \& Candemir, F. (2016). Spatial variability of soil physical properties in a cultivated field. Eurasian Journal of Soil Science, 5(3), 192-200.

Hautz, J., Mayer, M., \& Stadler, C. (2014). Macro-competitive context and diversification: the impact of macroeconomic growth and foreign competition. Long Range Planning, 47(6), 337-352.

Hebous, S. (2011). The effects of discretionary fiscal policy on macroeconomic aggregates: a reappraisal. Journal of Economic Surveys, 25(4), 674-707.

IASB. IFRS use around the World. Available on: http://archive.ifrs.org/Use-around-theworld/Pages/Jurisdiction-profiles.aspx. Acess on 06/22/2017

Jackson, A. B., Plumlee, M. A., \& Rountree, B. R. (2018). Decomposing the market, industry, and firm components of profitability: implications for forecasts of profitability. Review of Accounting Studies, 23(3), 1071-1095.

Jeon, H., \& Nishihara, M. (2014). Macroeconomic conditions and a firm's investment decisions. Finance Research Letters, 11(4), 398-409.

Jiménez, G., Ongena, S., Peydró, J. L., \& Saurina, J. (2012). Credit supply and monetary policy: Identifying the bank balance-sheet channel with loan applications. American Economic Review, 102(5), 2301-26.

Joshi, P., \& Giri, A. K. (2015). Examining the relationship between sectoral stock market indices and sectoral gross domestic product: an empirical evidence from India. Global Journal of Management And Business Research.

Kalemli-Ozcan, S., Kamil, H., \& Villegas-Sanchez, C. (2016). What hinders investment in the aftermath of financial crises: Insolvent firms or illiquid banks?. Review of Economics and Statistics, 98(4), 756769.

Kiley, M. T., \& Roberts, J. M. (2017). Monetary policy in a low interest rate world. Brookings Papers on Economic Activity, 2017(1), 317-396.

Klein, A., \& Marquardt, C. A. (2006). Fundamentals of accounting losses. The Accounting Review, 81(1), 179-206.

Konchitchki, Y. (2011). Inflation and nominal financial reporting: Implications for performance and stock prices. The Accounting Review, 86(3), 1045-1085.

Konchitchki, Y., \& Patatoukas, P. N. (2014). Accounting earnings and gross domestic product. Journal of Accounting and Economics, 57(1), 76-88.

Kruger, S. D., \& Petri, S. M. (2014). Novas evidências da relação entre medidas tradicionais de desempenho e aquelas baseadas na geração de valor a partir do custo de capital. Revista Universo Contábil, 10(2), $125-143$.

Leuz, C., \& Wysocki, P. D. (2016). The economics of disclosure and financial reporting regulation: Evidence and suggestions for future research. Journal of accounting research, 54(2), 525-622.

Li, N., Richardson, S., \& Tuna, İ. (2014). Macro to micro: Country exposures, firm fundamentals and stock returns. Journal of Accounting and Economics, 58(1), 1-20.

Mai, Y., Meng, L., \& Ye, Z. (2017). Regional variation in the capital structure adjustment speed of listed firms: Evidence from China. Economic Modelling, 64, 288-294.

Mankiw, N. G. (2016). Principles of macroeconomics. Cengage Learning. 
Moll, B. (2014). Productivity losses from financial frictions: Can self-financing undo capital misallocation?. American Economic Review, 104(10), 3186-3221.

Nardy, A., Famá, R., de Hoyos Guevara, J. A., \& Mussa, A. (2015). Verificação da ocorrência do efeito índice no Ibovespa-2004-2013. Revista de Administração, 50(2), 153-168..

Ray, S. (2012). Testing granger causal relationship between macroeconomic variables and stock price behaviour: evidence from India. Advances in Applied Economics and Finance, 3(1), 470-481.

Resić, E., Mangafić, J., Perić, T. Statistical analysis of causality between capital structure and firm profitability: Evidence from Bosnia and Herzegovina. Croatian Review of Economic, Business and Social Statistics, 2015, 1.1-2: 1-11.

Stolper, W. F. (1949). SAMUELSON, PAUL ANTHONY. Foundations of Economic Analysis. Pp. xii, 447. The ANNALS of the American Academy of Political and Social Science, 262(1), 223-225.

Shu, Y., Broadstock, D. C., \& Xu, B. (2013). The heterogeneous impact of macroeconomic information on firms' earnings forecasts. The British Accounting Review, 45(4), 311-325.

Silva, F. M., Coronel, D. A., \& Vieira, K. M. (2014). Causality and Cointegration Analysis between Macroeconomic Variables and the Bovespa. PloS one, 9(2).

Talla, J. T. (2013). Impact of macroeconomic variables on the stock market prices of the Stockholm stock exchange (OMXS30). Jonkoping International Business School.

Tarantin Junior, W., \& Valle, M. R. D. (2015). Estrutura de capital: o papel das fontes de financiamento nas quais companhias abertas brasileiras se baseiam. Revista Contabilidade \& Finanças, 26(69), 331-344.

Windmeijer, F. (2005). A finite sample correction for the variance of linear efficient two-step GMM estimators. Journal of econometrics, 126(1), 25-51.

World Bank. World Bank Open Data. Available on: http://data.worldbank.org/. Acess on: 08/12/2017.

Yang, E., Kim, S. H., Kim, M. H., \& Ryu, D. (2018). Macroeconomic shocks and stock market returns: The case of Korea. Applied Economics, 50(7), 757-773. 